\title{
Comparative Studies on Nanosulfur and Certain Fungicides to Control Cucumber Powdery Mildew Disease and their Residues in Treated Fruits
}

\author{
Hala R. Abdel-Rahman ${ }^{1}$ and Asmaa M.A. Alkolaly ${ }^{2}$
}

\begin{abstract}
The present work was carried out to explore the potential use of the new approach of sulfur nanoparticles compared with bulk sulfur and two other systemic fungicides to control powdery mildew in cucumber. Also, the Fungicide residues in cucumber were estimated. Examination of physico-chemical properties of the tested nanoparticles was done by using transmission electron microscope and $X$-Ray diffraction, which proved that the tested sulfur was sulfur $\left(S_{8}\right)$ with the crystal system and its anorthic and size ranged from 12.2 to $23.5 \mathrm{~nm}$. The three tested fungicides, Super sardo (azoxystrobin), Muringo (diniconazole), Thiofan (bulk sulfur) and Nanosulfur (Snp) were sprayed three times to cucumber growing in pots in a greenhouse. After $3^{\text {rd }}$ spray, the efficacy of the aforementioned tested fungicides was 74.0, 68.8, 42.7 and $60.9 \%$, respectively. The area under disease progress curve (AUDPC) in case of azoxystribin, bulk sulfur and Snp increased after $1^{\text {st }}$ and $2^{\text {nd }}$ sprays, but it decreased after $3^{\text {rd }}$ treatment. diniconazole recorded continues increase in disease area. Nanosulfur caused the highest number of fruits/plant, mean weight of fruits/plant and mean weight of one fruit and followed by azoxystribin and diniconazole, while bulk sulfur caused the lowest cucumber yield parameters. Assessment of residues of the four tested fungicides 2, 5 and 8 days after the third spray, showed that cucumber fruits can be collected two days after treatment with azoxystribin, bulk sulfur and Nanosulfur, while those treated with diniconazole can be harvested five days after spray.
\end{abstract}

Key Words: Cucumber, powdery mildew, fungi, Snp residues.

\section{INTRODUCTION}

Cucumber (Cucumis sativus L) is one of the most important delicious vegetable crops among the family Cucurbitaceae and it is consumed as a raw green fruit or in salads and pickles (Qudsia, et al. 2017). In Egypt, in 2017 the total cucumber production recorded 488.723 tones (FAO, 2017). It is well known that cucumber is a subject to the infestation by many pathogenic fungi (Mc Grath, 1996). Cucumber powdery mildew (CPM) caused by many fungi such as Golovinomyces cichoracearum s.l. (Gc) (syn. Erysiphe cichoracearum s.l.) and Podosphaera xanthii (Px) (syn. Sphaerotheca fuliginea) (Lebeda, 1983 and Kristkova, et al., 2009) which reduces the yield by an average of $20-40 \%$ by interfering with the plants physiological functions such as photosynthesis and respirations (Queiroga, et al. 2008 and Lamsal, et al. 2011). Powdery mildew leads also to extensive premature leaf defoliation, reduction of fruits size, inadequate fruit ripening, poor flavor and later wipes out the entire crop (Mc Grath, 1996). It is also worth to known that the yield loss is proportional to the disease severity and the length of time that plants have been infected (Mossler and Nesheim, 2005).

Different strategies for control powdery mildew diseases are very similar and depend on several farm practices. Fungicide treatments are and still remain so far, essential for maintaining healthy crops and reliable high-quality cucumber yield. These chemical compounds form a key component of integrated crop management, and their effectiveness must be sustained as long as possible (Brent and Hollomon, 2007). Chemical fungicides, which applied to control powdery mildew, are primarily preventive such as non-systemic, they are multi-site inhibitors and have a wide spectrum effect or/and curative such as systemic fungicides which they have specific single-site mode of action, therefore, they are effective against certain fungi (Kuck and Russell, 2006 and Mc Grath, 2001).

In 2017-2018, about 20 different fungicides belonging to different fungicide groups have been recommended to control cucumber powdery mildew in Egypt (Anonymous, 2017). However, many of the recommended fungicides had a high efficiency against powdery mildews fungi, continues application could lead to adverse impacts to the human health, terrestrial and aquatic ecosystems (Wightwick, et al, 2010). Moreover, agricultural industry since the last decade has faced problems arising from the development of resistance in fungal pathogens against the fungicides used (Brent and Hollomon, 2007).

One of the most oldest and important no-systemic fungicide groups is sulfur group which contains organic or elementary sulfur. However, elemental sulfur $(\mathrm{S})$ is the earliest eco-friendly fungicide for curing fungal infections in plants. It was registered as a non-systemic and contact fungicide. We hypothesize that intelligent

\footnotetext{
DOI: $10.21608 / A S E J A I Q J S A E .2020 .74243$

${ }^{1}$ Department of Economic Entomology and Pesticides, Faculty of Agriculture,

Cairo University

${ }^{2}$ Researcher in Integrated Control Research Department in Plant Pathol.

Res. Inst., A.R.C., Giza, Egypt

Received Januury 15,2020, Accepted February27, 2020
} 
nano science applications might increase the visibility of nano sulfur in agriculture as a potent and eco-safe fungicide (Choudhurya et.al., 2010 ). Recently, nanotechnology refers to an emerging field of science that includes synthesis and development of various nano-materials. Nanoparticles can be defined as objects ranging in size from 1- $100 \mathrm{~nm}$ (Anonymous, 2017). Presently, different metallic nano-materials are being produced using such as copper, zinc, titanium, magnesium, gold, alginate and silver. Moreover, nanoparticles are being used for diverse purposes, from medical treatments, using in various branches of industry production such as solar and oxide fuel batteries for energy storage, to wide incorporation into diverse materials of daily use such as cosmetics or clothes (Hassan, 2015).

The present investigation is designed to explore the potential use of sulfur nanoparticles to control powdery mildew on cucumber compared to bulk sulfur and two systemic fungicides, azoxystrobin and diniconazole. Additionally, examination of physicochemical properties of the tested sulfur nanoparticles was carried out by using transmission electron microscope (TEM) and X-Ray. The fungicide residues were also estimated in cucumber fruits after different time intervals of application.

\section{MATERIALS AND METHODS}

\section{Sulfur nanoparticles sample}

Sulfur (nanoparticles) was obtained from Chemical Engineering Department, Faculty of Engineering, Menia Univ., Egypt.

\section{Geochemical instrumentation and analysis}

Examination of physico-chemical properties of the tested sulfur nanoparticles was performed in Nanotechnology and Advanced Material Central Lab. (NAMCL), Agricultural Research Center (ARC) by using transmission electron microscope (TEM) of high resolution transmission (HR-TEM), Tecnai G20, Super twin, double ++++ tilt, with magnification range; up to $1,000,000 \mathrm{X}$ and elemental analysis "qualitative and semi-quantitative analysis". Two different modes of imaging were employed, the bright field at electron accelerating voltage $200 \mathrm{kV}$ using lanthanum hexaboride (LaB6) electron source gun, as well as, the diffraction pattern imaging. Eagle CCD camera with $(4 \mathrm{k} * 4 \mathrm{k})$ image resolution was used to acquire and collect transmitted electron images. TEM imaging and analysis (TIA) software was used to spectrum acquisition and analysis of EDX peaks the estimation of crystalline structure, morphology and mean size of nanoparticles. In addition, the average size of nanoparticles was determined.

\section{X-Ray diffraction}

X-Ray diffraction was carried out using XPERTPRO-P analytical- Netherland with the following parameter, X-Ray position [ ${ }^{\circ} 2 \mathrm{Th}$.]: 79.9900 , step size [ ${ }^{\circ}$ Th.]: 0.0200 , scan step time [s]: 0.5000, scan type: continuous, offset [ ${ }^{\circ} \mathrm{Th}$.]: 0.0000 , divergence slit type: fixed, divergence slit size $\left[^{\circ}\right]: 0.8709$, specimen length $[\mathrm{mm}]: \quad 10.00$, receiving slit size $[\mathrm{mm}]: 0.1000$, measurement temperature $\left[{ }^{\circ} \mathrm{C}\right]: 25.0$, and anode material: $\mathrm{Cu}(40 \mathrm{Kv}-30 \mathrm{~mA})$.

\section{Fungicides used}

Common, trade name, formulation and application rate of the tested fungicides are summarized in table (1).

Table . Trade name, common name, formulation and application rate of the tested fungicides

\begin{tabular}{lccc}
\multicolumn{1}{c}{$\begin{array}{c}\text { Trade } \\
\text { name }\end{array}$} & $\begin{array}{c}\text { Common } \\
\text { name }\end{array}$ & $\begin{array}{c}\text { Formulation } \\
\text { type }\end{array}$ & $\begin{array}{c}\text { Application } \\
\text { rate } \\
\text { /100L water }\end{array}$ \\
\hline $\begin{array}{l}\text { Super } \\
\text { sardo } \\
\text { Muringo }\end{array}$ & azoxystrobin & $50 \% \mathrm{SC}$ & $25 \mathrm{~cm}^{3}$ \\
diniconazole & $12.5 \% \mathrm{WP}$ & $15 \mathrm{gm}$ \\
Thiofan & sulfur & $80 \% \mathrm{WP}$ & $250 \mathrm{gm}$ \\
Nanosulfur & nanosulfur & $100 \% \mathrm{WP}$ & $10 \mathrm{gm}$ \\
\hline
\end{tabular}

\section{Pots experiments}

Cucumber seeds (vr. Beta Alfa) were sown under greenhouse conditions in 80 pots $(50 \mathrm{~cm}$ in diameter) containing sandy loam soil, where each of which was transplanted with five seeds. The pots were divided into 5 groups (treatments), each treatment contained 4 replicates, each of which contained 4 pots. All conventional agronomy treatments were applied and the plants were left for natural infection with powdery mildews. As soon as the mean severity of powdery mildew reached 5\%, azoxystrobin, diniconazole, sulfur, and sulfur nanoparticles (Snp) were suspended in water at the above mentioned rates and each group was sprayed with one of the four fungicides. All treatments were sprayed three times in 2 weeks intervals. The fifth group was not treated with any chemicals but received only water and served as a control treatment.

\section{Disease assessment}

Disease scale contained six categories was used as follows, $0=$ No symptoms of powdery mildew on leaves; $1=$ small scattered powdery mildew specks covering $1 \%$ or less leaf area; $2=$ small powdery lesions covering $>1-10 \%$ of leaf area; $3=$ powdery mildew enlarged lesions covering $>10-25 \%$ of leaf area; $4=$ powdery mildew lesions coalesce to form big patches 
covering $>25-50 \%$ leaf area and 5- big powdery patches covering $>50 \%$ of leaf area and defoliation occurred.

Disease severity (DS) was calculated according to Townsend and Heuberger (1943) using the following formula: $\mathrm{DS}(\%)=\Sigma(\mathrm{nv}) / \mathrm{NV} \times 100$

Where, n: Degree of infection according to the scale

$\mathrm{v}$ : Number of samples per category

$\mathrm{V}$ : Total number of samples screened

$\mathrm{N}$ : Highest degree of category

Area under disease progress curve (AUDPC) during the application periods, was calculated using the equation of Campbell and Madden (1990):

$$
\mathrm{n}-1
$$

$\operatorname{AUDPC}=\sum_{\mathrm{i}=1} \frac{\mathrm{yi}+\mathrm{y}(\mathrm{i}+1)}{2} \times\left(\mathrm{t}_{\mathrm{i}+1}-\mathrm{t}_{\mathrm{i}}\right)$

Where, AUDPC is the area under disease progress curve

yi: the disease severity assessed at the beginning of treatment and two weeks after each treatment

ti: time (14 days for each disease severity assessment)

$\mathrm{n}$ : the total number of observations

While, the efficiency of the tested fungicides was corrected using Abbott's formula (Abbott, 1925),

Corrected disease severity (efficacy) $\%=(\mathrm{X}-\mathrm{Y}) /$ $\mathrm{X} \times 100$

Where $\mathrm{X}$ - disease severity in the control, Y: disease severity in the treatment

\section{Fruit yield assessment}

Mean number of cucumber fruits/plant, mean weight of fruits/plant and mean weight/fruit in each treatment was calculated.

\section{Fungicides residues in cucumber fruits after Harvest time}

\subsection{Analytical method of azoxystrobine}

Fruit samples were collected from all replicates of azoxystrobin treated and untreated pots after last round of spraying to determine the harvest time residues. Samples were collected for dissipation studies at two, five and eight days after application. Fruit sample of 500 $\mathrm{g}$ was collected from each replicate, pooled and after quartering, $25 \mathrm{~g}$ of laboratory analytical samples in duplicates were drawn in wide mouth containers having extraction solvent, acetonitrile: doubled distilled water $(9: 1 \mathrm{v} / \mathrm{v})$. The working samples were transported in an ice box and stored at $-7^{\circ} \mathrm{C}$ in a deep-freezer in the laboratory.

\subsubsection{Extraction}

The fruit samples were homogenized with acetonitrile: water $(9: 1 \mathrm{v} / \mathrm{v})$. The extract was filtered under vacuum through a Buchner funnel overlaid with Whatman filter paper No.1 into a round bottom flask. For further extraction, the residues were washed with the same solvent. All the aliquots were evaporated to near dryness on rotary evaporator at $<40^{\circ} \mathrm{C}$ and re-dissolved in dichloromethane: ethyl acetate mixture (95:5) for silica gel column cleanup (Anand, et al., 2008).

\subsubsection{Clean up}

The residues were re-dissolved in 5-10 $\mathrm{ml}$ of HPLC grade acetonitrile for final determination using HPLC, Agielut 1100 [Mobile phase - Acetonitrile (HPLC grade): water (HPLC grade) (60:40 v/v), column - C18, flow rate $-1 \mathrm{ml} / \mathrm{min}$, wave length $-250 \eta \mathrm{m}$, quantity injected $-4.6 \mu \mathrm{l}$ (fixed loop), and attenuation - 3].

\subsection{Analytical method of diniconazole}

\subsubsection{Extraction}

The extraction method of Möllhoff (1975) was adopted for extraction of diniconazole from cucumber fruits. Fifty grams samples were placed in the blender cup with a constant amount of methanol ( $2 \mathrm{ml} / \mathrm{g}$ fruits), then blended for three minutes and filtered.

Extracts were shaken successively with 100 and 50 $\mathrm{ml}$ of methylene chloride in separator funnel after adding $40 \mathrm{ml}$ of sodium chloride solution (20\%), then the water phase discarded. The combined methylene chloride phases were dried by filtration through anhydrous sodium sulfate. Then, it was evaporated just to dryness using a rotary evaporated at $40^{\circ} \mathrm{C}$.

8.2.2 Clean-up of extracts and determination: The extract of diniconazole was cleaned up using GC (Algielnt 7890) equipped with Electron Capture Detector (ECD). GC determination: Quantitative analysis of diniconazole residues were performed by Perkin Elmer, series 4500 plus gas chromatograph (GC), where the injection port temperature was $200^{\circ} \mathrm{C}$, the column temperature was $230^{\circ} \mathrm{C}$, the run time $10 \mathrm{~min}$. and the detector temperature $250^{\circ} \mathrm{C}$. The carrier gas was nitrogen at a flow rate of $4 \mathrm{ml} / \mathrm{min}$. and the injection volume was $1 \mu \mathrm{l}$.

\subsection{Analytical method of Sulfur}

Advanced Microwave Digestion System was used for digestion of samples, where the concentrations of sulfur of various samples were determined by using Inductively Coupled Plasma (ICP-AES), Thermo Sci, model: iCAP6000 series Argon gas was used for excitation of the element atom. The blank values for each element were deduced from the sample values. This method provides for the acid digestion of the plant 
tissue $(0.5 \mathrm{~g})$ in a closed vessel device using temperature control microwave heating for the metal determination by spectroscopic methods. The reagents was $7 \mathrm{ml}$ of $\mathrm{HNO}_{3} 65 \%, 1 \mathrm{ml}$ of $\mathrm{H}_{2} \mathrm{O}_{2} 30 \%$. (Milestone srl.com, Innovation laboratory microwave system for sample preparation)

\section{Statistical analysis}

Disease severity, mean number of fruits/ plant and mean fresh weight of fruits/ plant and mean weight/fruit were statistically analyzed as a complete randomized block design and least significant differences (L.S.D 0.5) was calculated according to Fisher (1948) and Snedecor and Cochran (1967) and Multiple range and multiple F test (Duncan, 1955), using Web Agri. Stat Package Computer Program (WASP).

\section{RERSULTS}

\section{Geochemical instrumentation and analysis}

Examination of physico-chemical properties of the tested sulfur nanoparticles using transmission electron microscope (TEM) and X-Ray diffraction (XRD) revealed that the sample is sulfur $\left(\mathrm{S}_{8}\right)$ with the following crystal graphic parameters:

Crystal system: anorthic, space group: $\mathrm{P}-1$, space group number: 2, a (A): 6.113 4, b (A): 10.7116 , c(A ): 5.9584 , Alpha $\left({ }^{\circ}\right): 82.3760$, Beta $\left({ }^{\circ}\right): 107.3230$ and Gamma $\left({ }^{\circ}\right)$ : 102.594 0,volume of cell $\left(10^{\wedge} 6\right.$ prn-^3): 3 62.5 6, Z: 2 . 0 0, RIR: 0.9 9, and nanoparticles size ranged from 12.2 to $23.5 \mathrm{~nm}$ with very high purity (Figures 1and 2).

\section{Pots experiments}

Calculating disease severity and fungicides effectiveness revealed that, there were significant

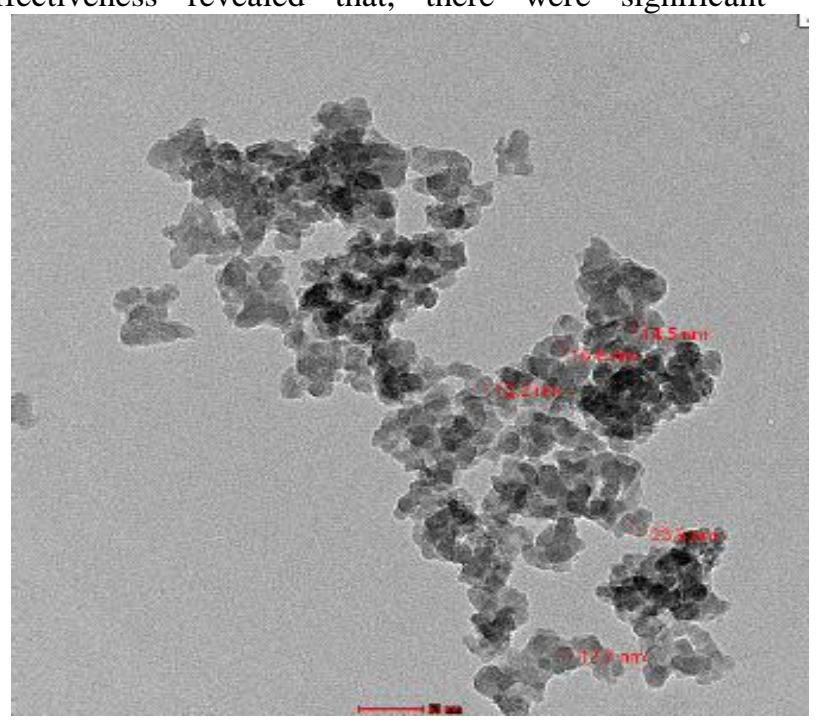

differences in disease severity between the control and all other treatments. At the same time, there were significant differences among all treatments treated with the tested fungicide, except between plants treated with azoxystrobin and those treated with diniconazole.

The percentages of fungicides efficacy after the first spray showed that azoxystrobin was the most effective fungicide recorded $49.8 \%$, followed by diniconazole with $46.7 \%$, then (Snp) with $31.0 \%$, while bulk sulfur was the least effective treatment with only $21.6 \%$ in disease severity (Table 2).

After the second spray, the disease severity in different treatments showed the same trend since, azoxystrobin and diniconazole were found at the same category with 8.7 and $8.5 \%$ and followed by bulk with $17 \%$ sulfur, while Snp with $13.2 \%$ was the least effective fungicide compared with $22.15 \%$ in control, respectively. Generally, the fungicides efficacy for the aforementioned fungicides reached 60.7, 61.6, 40.0 and $23.3 \%$, respectively.

After the third spray, the differences among disease severities in different treatments, showed that there were significant differences among all the treatments even between azoxystrobin and diniconazole. The treatments can be arranged according to disease severity in descending order as follow: azoxystrobin, diniconazole, Snp then bulk sulfur with $10,12,15$ and $22 \%$ compared with $38.4 \%$ in control treatment. After the third spray, the tested fungicides, azoxystrobin, diniconazole, bulk sulfur and Snp recorded 74.0, 68.8, 42.7 and 60.9\% efficacy as represented by reduction in disease severity, respectively (Table 2 ).

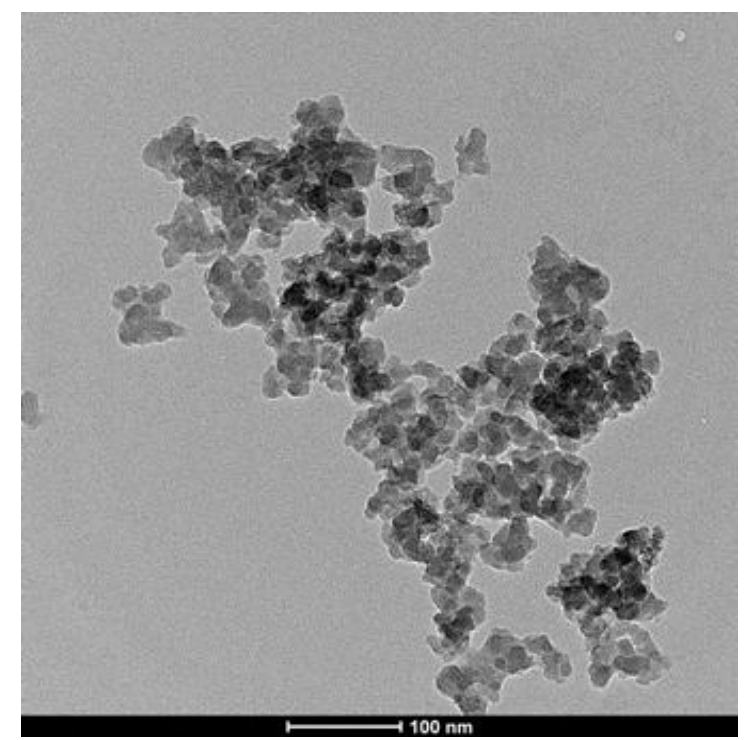

Figure 1. ETM pictures show the geochemical properties of S nanoparticles, their shape and size which ranged from 12.2 to $23.5 \mathrm{~nm}$ 


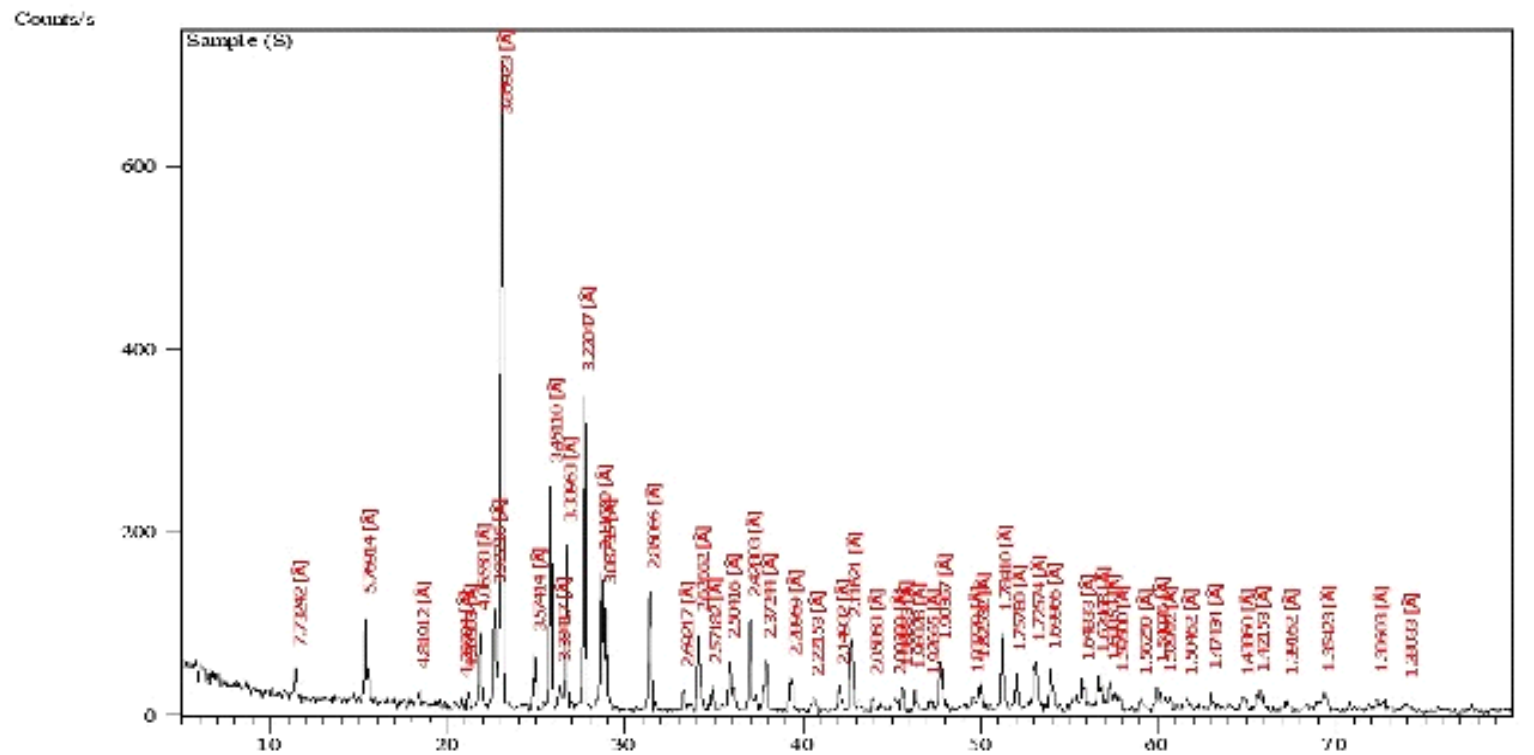

Figure 2.XRD diagram shows $X r$ diffraction through $S$ nanoparticles crystals at the positions, 16, 19, 31.8 and $50.5^{\circ}$ theta, absent of any other sharp picks confirms the high purity of sample

Table 2. Powdery mildew disease severity and fungicide efficacy $(\%)$ of cucumber plants treated with sulfur nanoparticles (Snp) compared with plants treated with three conventional fungicides after three sprays

\begin{tabular}{ccccccc}
\hline & \multicolumn{2}{c}{ After $1^{\text {st }}$ Spray } & \multicolumn{2}{c}{ After $2^{\text {nd }}$ Spray } & \multicolumn{2}{c}{ After $3^{\text {rd }}$ Spray } \\
\cline { 2 - 7 } Treatments & $\begin{array}{c}\text { Disease } \\
\text { severity }\end{array}$ & $\begin{array}{c}\text { Fungicide } \\
\text { efficacy } \\
\%\end{array}$ & $\begin{array}{c}\text { Disease } \\
\text { severity }\end{array}$ & $\begin{array}{c}\text { Fungicide } \\
\text { efficacy } \\
\%\end{array}$ & $\begin{array}{c}\text { Disease } \\
\text { severity }\end{array}$ & $\begin{array}{c}\text { Fungicide } \\
\text { efficacy \% }\end{array}$ \\
\hline Azoxystrobin & $6.4^{\mathrm{d}}$ & 49.8 & $8.7^{\mathrm{d}}$ & 60.7 & $10.0^{\mathrm{e}}$ & 74.0 \\
Diniconazole & $6.8^{\mathrm{cd}}$ & 46.7 & $8.5^{\mathrm{d}}$ & 61.6 & $12.0^{\mathrm{d}}$ & 68.8 \\
Bulk sulfur & $10.0^{\mathrm{b}}$ & 21.6 & $17.0^{\mathrm{b}}$ & 23.3 & $22.0^{\mathrm{b}}$ & 42.7 \\
Sulfur (Snp) & $8.8^{\mathrm{c}}$ & 31.0 & $13.2^{\mathrm{c}}$ & 40.0 & $15.0^{\mathrm{c}}$ & 60.9 \\
Control & $12.75^{\mathrm{a}}$ & -- & $22.15^{\mathrm{a}}$ & -- & $38.4^{\mathrm{a}}$ & -- \\
L.S.D. (0.05) & 1.641 & -- & 2.154 & -- & 1.65 & -- \\
\hline
\end{tabular}

Means followed by the same letters have no significant differences

Concerning the area under disease progress curve (AUDPC), the present results as shown in Table (3) proved that, however the disease showed progress development in control treatment, it recorded 54.25, 65.8 and 113.75 area after the first, second and third spray with a total disease area of 233.8 , respectively, while azoxystrobin showed only 9.8 area after the first spray, increased to 16.1 after the second one, then it considerably decreased to 9.1 after the third spray with a total area of 35.0

Bulk sulfur and Snp react showed the same trend, where bulk sulfur resulted in disease area of 35, 49 and
35 after the three successive sprays with a total disease progress area of 119.0. Snp resulted in 26.6, 30.8 and then decreased to12.6 with a total disease progress area of 70 .

In contrast, diniconazole recoded continues an increase in disease area and it resulted in 11.9, 12.6 and 24.5 after $1^{\text {st }}, 2^{\text {nd }}$ and $3^{\text {rd }}$ spray with a total disease progress area of 49.0 (Table 3 ).

Yield assessment indicated that sulfur nanoparticles (Snp) caused the highest mean number of fruits/ plant, mean weight of fruits/ plant and also mean weight of one fruit recording 8 fruits, $750 \mathrm{~g}$ fruit/plant and $93.8 \mathrm{~g} /$ fruit, 
Table 3.Area under disease progress curve (AUDPC) and cucumber yield parameters after four fungicides sprays

\begin{tabular}{lccccccc}
\hline & \multicolumn{3}{c}{ Area under Disease Progress Curve (AUDPC) } & \multicolumn{3}{c}{ Cucumber yield parameters (mean) } \\
\cline { 2 - 7 } \multicolumn{1}{c}{ Treatments } & $\begin{array}{c}\text { After } 1^{\text {st }} \\
\text { Spray }\end{array}$ & $\begin{array}{c}\text { After 2 } \\
\text { Spray }\end{array}$ & $\begin{array}{c}\text { After } 3^{\text {rd }} \\
\text { Spray }\end{array}$ & Total area & $\begin{array}{c}\text { number of } \\
\text { fruits/ plant }\end{array}$ & $\begin{array}{c}\text { weight of } \\
\text { fruits/ plant (g) }\end{array}$ & $\begin{array}{c}\text { weight of } \\
\text { one fruit (g) }\end{array}$ \\
\hline Azoxystrobin & 9.8 & 16.1 & 9.1 & 35.0 & $6^{\mathrm{b}}$ & $455^{\mathrm{b}}$ & $75.8^{\mathrm{b}}$ \\
Diniconazole & 11.9 & 12.6 & 24.5 & 49.0 & $5^{\mathrm{bc}}$ & $350^{\mathrm{c}}$ & $70.0^{\mathrm{c}}$ \\
Bulk sulfur & 35.0 & 49.0 & 35.0 & 119.0 & $4^{\mathrm{c}}$ & $200^{\mathrm{d}}$ & $50.0^{\mathrm{d}}$ \\
Sulfur (Snp) & 26.6 & 30.8 & 12.6 & 70.0 & $8^{\mathrm{a}}$ & $750^{\mathrm{a}}$ & $93.8^{\mathrm{a}}$ \\
Control & 54.25 & 65.8 & 113.75 & 233.8 & $2^{\mathrm{d}}$ & $88^{\mathrm{e}}$ & $44.0^{\mathrm{e}}$ \\
L.S.D. (0.05) & -- & -- & -- & -- & 1.64 & 8.49 & 5.2 \\
\hline
\end{tabular}

Means in the same column followed by the same letters have no significant differences

Table 4.Residues of azoxystrobin, diniconazole, bulk sulfur and nanosulfur in cucumber fruits 2,5 and 8 days after treatment of the third spray

\begin{tabular}{ccccc}
\hline \multirow{2}{*}{ Days after spraying } & \multicolumn{4}{c}{ Residue of Fungicides (ppm) } \\
\cline { 2 - 5 } & Azoxystrobin & Diniconazole & Sulfur & Nanosulfur \\
\hline 2 days & 0.52 & 0.086 & 0.013 & 0.012 \\
5 days & 0.48 & 0.038 & 0.011 & 0.012 \\
8 days & 0.14 & 0.01 & 0.006 & 0.007 \\
MRL & 1 & 0.01 & 1 & 1 \\
\hline
\end{tabular}

MRL: Maxim Residue Level

respectively.Azoxystrobin came second in its efficiency and recorded 6 fruits/plant, $455 \mathrm{~g}$ fruit/plant and 75.8 $\mathrm{g} /$ fruit, while diniconazole recorded 5 fruits/plant, $350 \mathrm{~g}$ fruits/plant and $70.0 \mathrm{~g} /$ fruit. Bulk sulfur caused the lowest yield parameters where it gave only 4 fruits/ plant, $200 \mathrm{~g}$ fruit/plant and mean weight of one fruit was $50 \mathrm{~g}$ (Table 3).

\section{Fungicides residual analysis}

Table (4) illustrated the residue levels of the tested fungicides 2, 5 and 8 days after the third spray to cucumber. It was noticed that two and eight days after treatment, the azoxystrobin levels were 0.52 and 0.48 ppm, diniconazole levels were 0.086 and $0.038 \mathrm{ppm}$, sulfur levels were 0.013 and $0.011 \mathrm{ppm}$, while Snp levels were 0.012 and $0.012 \mathrm{ppm}$, respectively.

\section{DISCUSSION}

Cucumber powdery mildew (CPM) is a very serious disease interfere with the plants physiological functions such as photosynthesis and respirations leading to extensive premature defoliation of leaves, reduction of fruits size and later wipes out, causing a yield reduction of 20-40\% (Mc Grath, 1996; Queiroga., et al. 2008 and Lamsal., et al. 2011). However, fungicides are and remain bedrock in all integrated crop management programs. Nanoparticles are a new approach in different agricultural fields (Tegart, 2003). It is well known that the two curative systemic fungicides azoxystrobin and diniconazole were the highest efficient compounds compared to the two sulfur compounds (sulfure and Snp) against cucumber powdery mildew disease. The present data is in harmony with (Mc Callan, 1949; Baldwin et al. 1996 and Wilcox et al., 1999). Nanosulfur was significantly more effective than bulk sulfur and this efficacy may be due to the very ultra-fine particles of nanosulfur. Similarly, Sarsar et al., (2014) referred the increased efficacy of nanosilver compared with bulk silver due to nanosilver has a very large surface area, which typically results in a greater biological activity in addition to its chemical reactivity and catalytic behavior compared to larger particles of the same chemical composition.

Area under disease progress (AUDP) indicated that, after the first and second sprays of azoxystribin, bulk sulfer and nanosulfur, the disease area gradually increased. After that, the disease area significantly decreased after the third spray in contrast to diniconazole since the disease continued to increase. This continuous increase of the disease area may due to the buildup of resistant strains of the fungus against diniconazole compound. These findings agree with those of Brien et al., (1988) who found that the fungicides penconazole were less effective in controlling the powdery mildew disease compared with earlier field trials results and suggested that fungicide resistant strains may have developed.

Surprisingly, nanosulfer resulted in 70.0 total areas under disease progress curve, compared with only 35.0 
and 49.0 in case of azoxystrobin and diniconazole, respectively. On the other hand, the present results showed that cucumber yield in plots treated with nanosulfur recorded the highest mean number of fruits/ plant and mean weight of one fruit and accordingly highest mean weight of fruits/ plant (750 g) compared to only 455 and $350 \mathrm{~g}$ for cucumber treated with azoxystrobin and diniconazole, respectively. These results are in harmony with those obtained by Salem et al. (2016) who found that nanosulfure increased the yield of Cucurbita pepo and improved the morphological parameters of the treated plants in addition to reduce the plant infection with fungi in plots treated with azoxystrobin and diniconazole.

It is well known that sulfur is an important component of enzyme and protein synthesis, and is also required for chlorophyll formation. In addition to its important for plant yield, it was found that its foliar application can be more effective to increase the yield than soil applied fertilizer (Zuchi, et al., 2015 and Anonymous, 2019).

Concerning residual analysis studies, assessment of residues of the four tested fungicides and according to EU Pesticides Database, it was found that after two and five days azoxystrobin, bulk sulfur and nanosufur residues were under the level of maximum residue limit (MRL), so it is recommended to pick up the fruits two days after treatment with any of the three aforementioned fungicides. However, the fruits which were treated with diniconazole, it is not recommended to harvest the fruits before five days.

\section{REFERENCES}

Abbott, W. S. 1925. A method of computing the effectiveness of an insecticide. J. econ. Entomol 18 (2):265-267.

Anand, T., A. Chandrasekaran, S. Kuttalam, G. Senthilraja, T. Raguchander, and R. Samiyappan. 2008. Effectiveness of azoxystrobin in the control of Erysiphe cichoracearum and Pseudoperonospora cubensis on cucumber. Journal of Plant Protection Research 48 (2):147-159.

Anonymous. 2017. NPIC Product Research Online (NPRO): Sulfur; . National Pesticide Information Center:Corvallis, $O R$.

Anonymous. 2019. Role of Sulfur in Tomato Production. . Product Info and Safety Data Sheets, Yara, United States.

Baldwin, B., J. Clough, C. Godfrey, J. Godwin, and T. Wiggins. 1996. The discovery and mode of action of ICIA5504. Modern fungicides and antifungal compounds:69-77.

Brent, K., and D. Hollomon. 2007. Fungicide resistance in crop pathogens: how can it be managed? Fungicide Resistance Action Committee. Brussels, Belgium.

Campbell, C. L., and L. V. Madden. 1990. Introduction to plant disease epidemiology: John Wiley \& Sons. de Queiroga, R. C. F., M. Puiatti, P. C. R. Fontes, and P. R. Cecon. 2008. Produtividade e qualidade de frutos de meloeiro variando número de frutos e de folhas por planta. Horticultura Brasileira 26 (2):209-215.

Duncan, D. B. 1955. Multiple range and multiple F tests. Biometrics 11 (1):1-42.

FAO. 2017. Faostat database available from http://faostat:fao.org. Accessed date.

Fisher R.A. 1948. Statistical Methods 6th ed. Iowa StateUniv.Press, Ames, Iowa, USA.

Hassan, S., 2015. . 2015. A Review on Nanoparticles:Their Synthesis and Types. Research Journal of Recent Sciences, 4: 1-3.

Kř́stková, E., A. Lebeda, and B. Sedláková. 2009. Species spectra, distribution and host range of cucurbit powdery mildews in the Czech Republic, and in some other European and Middle Eastern countries. Phytoparasitica 37 (4):337-350.

Kuck, K., and P. Russell. 2006. FRAC: Combined resistance risk assessment. Aspects of Applied Biology 78:3.

Lamsa, K., S.-W. Kim, J. H. Jung, Y. S. Kim, K. S. Kim, and Y. S. Lee. 2011. Inhibition effects of silver nanoparticles against powdery mildews on cucumber and pumpkin. Mycobiology 39 (1):26-32.

Lebeda, A. 1983. The genera and species spectrum of cucumber powdery mildew in Czechoslovakia. Journal of Phytopathology 108 (1):71-79.

McCallan, S. E. A. 1949. The nature of the fungicidal action of copper and sulfur. The Botanical Review 15 (9):629643.

McGrath, M. 1996. Successful management of powdery mildew in pumpkin with disease threshold-based fungicide programs. Plant disease (USA).

McGrath, M. T. 2001. Fungicide resistance in cucurbit powdery mildew: experiences and challenges. Plant disease 85 (3):236-245.

Mollhoff, E. 1975. Method for gas chromatographic determination of residues of Tokuthion and its oxon in plants and soil samples. Pflanzenschutz Nachrichten.

Mossler, M., and O. Nesheim. 2005. Florida Crop/Pest Management Profile: Squash. Electronic Data Information Source of UF/IFAS Extension (EDIS). CIR 1265. February, 3, 2005.

O'Brien, R., L. Vawdrey, and R. Glass. 1988. Fungicide resistance in cucurbit powdery mildew (Sphaerotheca fuliginea) and its effect on field control. Australian journal of experimental agriculture 28 (3):417-423.

Qudsia, H., A. Javaid, R. Mahmood, and N. Akhtar. 2017. Correlation between soil chemical characteristics and soilborne mycoflora in cucumber tunnels. Pak J Bot 49 (4):15791583.

Salem, N. M., L. S. Albanna, A. M. Awwad, Q. M. Ibrahim, and A. O. Abdeen. 2016. Green synthesis of nano-sized sulfur and its effect on plant growth. J. Agric. Sci 8 (1):188. 
Sarsar, V., K. K. Selwal, and M. K. Selwal. 2014. Nanosilver: potent antimicrobial agent and its biosynthesis. african journal of Biotechnology 13 (4).

Snedecor, G. W., and W. G. Cochran. 1967. Statistical methods, 6th edn. Ames. Iowa, USA: Iowa State University Press 129:31.

Tegart, G. 2003. Nanotechnology: The technology for the 21st Century. APEC Center for Technology Foresight, Bangkok.

Townsend, G. R., and J. W. Heuberger. 1943. Methods for estimating losses caused by diseases in fungicides experiments. Plant Disease Reporter 27:340-343.
Wightwick, A., R. Walters, G. Allinson, S. Reichman, and N. Menzies. 2010. Environmental risks of fungicides used in horticultural production systems. Fungicides:273-304.

Wilcox, W., D. Riegel, and F. Wong. 1999. Evaluation of fungicide programs for control of grapevine downy mildew. Fungic. Nematic. Tests 54:111.

Zuchi, S., M. Watanabe, H. M. Hubberten, M. Bromke, S. Osorio, A. R. Fernie, S. Celletti, A. R. Paolacci, G. Catarcione, and M. Ciaffi. 2015. The interplay between sulfur and iron nutrition in tomato. Plant Physiology 169 (4):2624-2639.

\title{
الملخص العربي
}

\section{دراسات مقارنة لدور الكبريت النانو وبعض المبيدات الفطرية في مكافحة مرض البياض الاقيقي في نبات الخيار وتقدير متبقياتها في الثمار}

\author{
هالة رشاد عبد الرحمن و أسماء محمود القللي
}

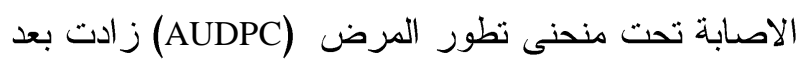

الرشة الأولى والثانية ولكنها إنخفضت بشكل ملحوظ بعد

الرشة الثالثة وذلك لمركبات azoxystribon و و و Sulfur nanoparticles عكس مركب diniconazole و الذي أدي إلى زيادتها بعد كل الرشات الثلاثة. أدت المعاملة بالكبريت النانو إلى أكبر زيادة في عدد الثمار/النبات وكذللك

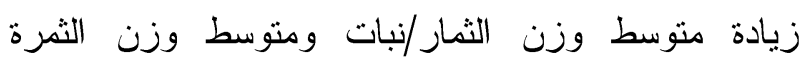

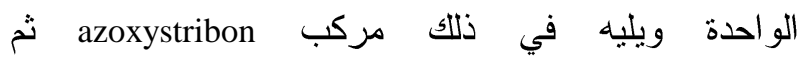
diniconazole المعاملة به إلى أقل معايير كمية ووزن ثمار الخيار. أما بالنسبة لتقدير منبقيات المركبات محل الدراسة بعد جمع وتحليل عينات منها بعد Y و 0 و م أيام بعد الرش

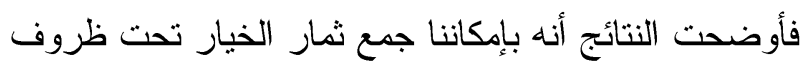
الدراسة بعد يومين من الرش بوجه عام وذللك بالنسبة

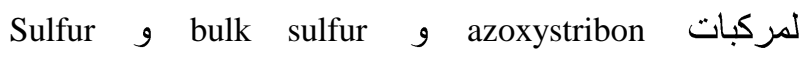
nanoparticles diniconazole
يهدف هذا البحث الى در اسة امكانية استخدام الكبريت النانو (حبيبات متتاهية الصغر) بالمقارنة بمستحضر الكبريت المعدني ومبيدين فطريين آخرين وذلك لمكافحة مرض البياض الاقيقي الذي يصيب نبات الخيار. كما تم تقدير متبقيات تلك المركبات في ثمار الخيار لبيان الفترة الي يوصى بعدها بجمع المحصول بعد المعاملة. وبإختبار الخو اص الطبيعية الكيميائية لجزيئات النانو لمركب الكبريت باستخدام الميكروسكوب الإليكتروني الناقل بالاضافة الى أنثعة اكس و التي أثتتت أن هذا الكبريت هو S8 و الذي يتميز بحبيبات بللورية الثكل حيث يتراوح طول حبيباتها بين

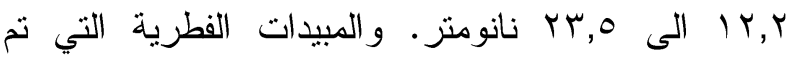
Sر استها هي (diniconazole), Thiofan (bulk sulfur) and Sulfur nanoparticles (Snp) نباتات الخيار المنزرعة في أصص ( •. سم) تحت ظروف البيت المحمي. كانت نسبة الخفض في شدة الاصابة بعد

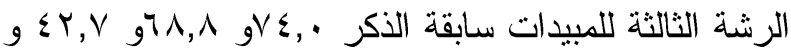
9, . \% على الترتيب. أوضحت الدراسة أن مساحة 